\title{
Short communication: Effects of moringa extract on adhesion and invasion of Escherichia coli 055 in bovine mammary epithelial cells
}

\author{
W. N. Cheng, $\odot$ C. H. Jeong, D. H. Kim, and S. G. Han* () \\ Department of Food Science and Biotechnology of Animal Resources, Konkuk University, Seoul 05029, Republic of Korea
}

\section{ABSTRACT}

The objective of this study was to evaluate the antibacterial activities of extract derived from moringa leaves. In particular, the effect of moringa extract (Mor) on adhesion and invasion of Escherichia coli O55, Enterococcus faecalis, Staphylococcus simulans, and Serratia liquefaciens was evaluated in bovine mammary epithelial cells (MAC-T). Broth microdilution method, minimum inhibitory concentration and minimum bactericidal concentration assays, adhesion and invasion assays, and real-time PCR were performed. The minimum inhibitory concentration and minimum bactericidal concentration of Mor ranged from 12.5 to $50 \mathrm{mg} / \mathrm{mL}$ on 18 out of 27 tested isolates. Treatment of E. coli $\mathrm{O} 55$ with Mor $(100$ and $200 \mu \mathrm{g} / \mathrm{mL})$ inhibited the adhesion and invasion on MAC-T cells via downregulation of adhesion factors (i.e., papC, $f 17 c-\mathrm{A}$, and eaeA). Also, when MAC-T cells were pretreated with Mor $(200 \mu \mathrm{g} / \mathrm{mL}, 12 \mathrm{~h})$ and incubated with E. coli O55, Enterococcus faecalis, Staphylococcus simulans, or Serratia liquefaciens, both E. coli O55 and Enterococcus faecalis showed a significant decrease in adhesion and invasion. Staphylococcus simulans exhibited decreased adhesion and increased invasion. Serratia liquefaciens showed increased adhesion and decreased invasion. In addition, Mor increased mRNA expression of antioxidant enzymes (e.g., heme oxygenase-1, NAD $(\mathrm{P})$ $\mathrm{H}$ :quinone oxidoreductase-1, and thioredoxin reductase 1) in MAC-T cells. In conclusion, 12.5 to $50 \mathrm{mg} / \mathrm{mL}$ of Mor exhibited antibacterial activity against 18 out of 27 tested isolates. Also, pretreatment of $200 \mu \mathrm{g} / \mathrm{mL}$ of Mor to MAC-T cells modulated adhesion and invasion of E. coli O55 and other mastitis-associated pathogens. Furthermore, Mor increased antioxidant capacities in MAC-T cells, but further in vivo studies are needed. Key words: moringa, bovine mastitis, bovine mammary epithelial cells, antimicrobial effects, antioxidant effects

\footnotetext{
Received October 22, 2019.

Accepted March 25, 2020.

*Corresponding author: hansg@konkuk.ac.kr
}

\section{Short Communication}

Bovine mastitis is characterized by inflammation of the mammary gland in dairy cattle (Oviedo-Boyso et al., 2007). Bovine mastitis is the most common disease in dairy cows, causing economic losses in the dairy industry worldwide due to decreased milk production, discarded milk, veterinary services, labor, product quality, and culling (Halasa et al., 2007). Numerous microorganisms have been identified as potential pathogens in mastitis with the majority of infections caused by staphylococci (e.g., Staphylococcus aureus), streptococci (e.g., Streptococcus uberis), and enterobacteria (e.g., Escherichia coli) (Watts, 1988). These bacteria produce many virulence factors such as microbial surface components recognizing adhesive matrix molecules, adhesin, and other substances that facilitate bacterial colonization and internalization to the host cells (Ghanbarpour and Oswald, 2010; Gogoi-Tiwari et al., 2015). The main treatment for bovine mastitis is antibiotic therapy during the dry period and lactation (Oliver and Sordillo, 1988; Erskine et al., 2003). However, due to the emergence of antibiotic-resistant microorganisms, researchers are searching for new alternative approaches, especially natural compounds, to control bovine mastitis. In contrast to antibiotics, natural compounds are economical, easily available, and affordable (Rakholiya et al., 2013). More importantly, plant-derived antibacterial substances can possibly decrease the selective pressure on development of antibiotic resistance (Lewis and Ausubel, 2006). In fact, natural products isolated from plants were reported to exert antimicrobial activities, for example, root extract of Thalictrum minus L. and its isolated constituents were reported to have antimicrobial effects against Staphylococcus xylosus, Staphylococcus lentus, Staphylococcus equorum, Enterococcus faecalis, and Pantoea agglomerans (Mushtaq et al., 2016). The combination of Eucalyptus globulus and Juglans regia was reported to have antibacterial activities against Staphylococcus aureus isolates through reducing their virulence factor (i.e., biofilm formations) (Gomes et al., 2019).

In addition to virulence of pathogens, the defensive role of host cells is also important in bovine mastitis. 
The dairy cow body has an endogenous antioxidant defense system such as antioxidant enzymes that help to encounter the production of reactive oxygen species (ROS) during metabolisms (Sordillo and Aitken, 2009). However, during the periparturient period, production of ROS overwhelms the antioxidant defense system, resulting in increased oxidative stress and the risk of various bovine diseases including mastitis (Bernabucci et al., 2005; Sordillo and Aitken, 2009). One of the strategies to delay, prevent, or remove these oxidative damages is through supplementation of antioxidants (e.g., vitamin C and selenium) (Sordillo, 2018). Indeed, antioxidant-rich plant and plant-derived substances such as pomegranate (Safari et al., 2018) and resveratrol (Jin et al., 2016) were reported to improve the antioxidant status of the dairy cow and bovine mammary epithelial cells.

Moringa oleifera is a tree native to India that has high nutritive values. The leaves are rich in minerals, vitamins, and other bioactive components (e.g., quercetin, kaempferol derivatives, rutin, apigenin, chlorogenic acid, caffeoylquinic acid, and feruloylquinic acid) (Atawodi et al., 2010; Nouman et al., 2016) that have potential antioxidant, anti-inflammatory, and antimicrobial activity (Gopalakrishnan et al., 2016; VergaraJimenez et al., 2017). In our previous study, extract of $M$. oleifera leaves (Mor), was found to exhibit anti-inflammatory and antioxidative effects in bovine mammary cells (MAC-T) upon stimulation with LPS (Cheng et al., 2019). However, its effect on mastitis bacteria has yet to be investigated. Therefore, since Mor contains phytochemicals that exhibit antimicrobial and antioxidant activities, we hypothesized that (1) Mor has antimicrobial effects on bovine mastitis-associated pathogens, (2) Mor is able to modulate the adhesion and invasion of mastitis-associated pathogens, and (3) Mor can increase the antioxidant capacities of bovine mammary epithelial cells. We performed the following experiments to test our hypotheses.

The Mor was prepared according to a previous study (Cheng et al., 2019). Briefly, $20 \mathrm{~g}$ of moringa leaf powder (Philippine Moringa \& More Corporation, Rizal, Philippine) was added to $200 \mathrm{~mL}$ of $80 \%$ (vol/vol) methanol, and stirred for $3 \mathrm{~h}$ at room temperature. The mixture was then filtered with Whatman No. 1 filter paper (GE Healthcare Life Sciences, Buckinghamshire, UK) and the remaining solvent was evaporated under reduced pressure at $50^{\circ} \mathrm{C}$ using a rotary evaporator (Tokyo Rikakikai Co. Ltd., Tokyo, Japan). Residues (i.e., Mor) were freeze-dried and stored at $-80^{\circ} \mathrm{C}$ until use. The Mor was dissolved in dimethyl sulfoxide (DMSO; Amresco, Solon, OH) at $400 \mathrm{mg} / \mathrm{mL}$ and filtered with a $0.22-\mu \mathrm{m}$ syringe filter before usage.
We determined the MIC and minimum bactericidal concentration (MBC) of Mor against 27 bacteria, $E$. coli O55 (KVCC-BA0002381) that was obtained from the Korea Veterinary Culture Collection (Gimcheon, Korea), and 10 gram-negative and 16 gram-positive bacteria that were isolated from milk samples in cows with mastitis (Gyeonggi-do, Korea). Bacteria were grown on tryptone soy agar (TSA; BD-Difco, Sparks, MD) overnight, and a single colony from TSA was inoculated in $10 \mathrm{~mL}$ of tryptone soy broth (TSB; BDDifco) and incubated for overnight at $37^{\circ} \mathrm{C}$ with shaking (150 rpm). Then, $100 \mu \mathrm{L}$ of incubated bacterial culture was inoculated in $10 \mathrm{~mL}$ of TSB and allowed to grow in an incubator at $37^{\circ} \mathrm{C}$ and $150 \mathrm{rpm}$, until reaching $10^{8} \mathrm{cfu} / \mathrm{mL}$.

Broth microdilution method was performed as described by the Clinical and Laboratory Standards Institute with some modifications (CLSI, 2018). Briefly, 400 $\mathrm{mg} / \mathrm{mL}$ of Mor stock was diluted with TSB to $100 \mathrm{mg} /$ $\mathrm{mL}$, then a 2-fold serial dilution of Mor $(50,25,12.5$, $6.25 \mathrm{mg} / \mathrm{mL}$ ) was prepared. All the diluted samples contain the final concentration of $25 \%$ of DMSO in the solution. Next, $100 \mu \mathrm{L}$ of each sample was added to a sterile polystyrene 96 -well plate, followed by inoculation of $100 \mu \mathrm{L}$ of bacterial inoculum (approximately $10^{6} \mathrm{cfu} /$ $\mathrm{mL}$ ) to reach the final concentrations of $50,25,12.5$, $6.25,3.125$, and $0 \mathrm{mg} / \mathrm{mL}$. The highest concentration of Mor was selected based on the study of El Sohaimy et al. (2015), where MIC of methanolic extracts of moringa leaves were reported to be $40 \mathrm{mg} / \mathrm{mL}$ against Staphylococcus aureus, Staphylococcus epidermis, Streptococcus pyogenes, Escherichia coli, Bacillus subtilis, and Salmonella Senftenberg (El Sohaimy et al., 2015). The plate was incubated for $24 \mathrm{~h}$ at $37^{\circ} \mathrm{C}$. The MIC was defined as the lowest concentration at which no visible turbidity was observed. To determine MBC, $100 \mu \mathrm{L}$ of medium from a growth-free well was cultured on TSA and incubated for $24 \mathrm{~h}$ at $37^{\circ} \mathrm{C}$. Bacterial growth was determined by the formation of bacterial colonies on TSA. The lowest concentration of Mor with no growth of bacterial colonies was indicated as the MBC. Three isolates were randomly selected for identification to be used for the next experiments. The isolates were identified as Enterococcus faecalis, Staphylococcus simulans, and Serratia liquefaciens.

The MAC-T cells were cultured in Dulbecco's modified Eagle's medium (Welgene, Gyeongsan, Korea) supplemented with $10 \%$ fetal bovine serum (Welgene), $5 \mu \mathrm{g} / \mathrm{mL}$ insulin (Sigma-Aldrich, St. Louis, MO), and $1 \mathrm{\mu g} / \mathrm{mL}$ progesterone (Sigma-Aldrich) in 10-cm cell culture dishes in a $\mathrm{CO}_{2}$ humidified incubator at $37^{\circ} \mathrm{C}$ (Jeong et al., 2017; Cheng et al., 2019). The MAC-T cells (passage 20 to 30 ) were seeded in 6-well plates and 
allowed to grow to reach a monolayer with confluence of approximately 80 to $90 \%$ for cell treatments.

We studied the effect of Mor on adhesion and invasion of E. coli O55 in MAC-T cells according to a previous study with some modifications (Döpfer et al., 2000). Serogroup O55 is one of the most prevalent serotypes of $E$. coli isolated from mastitis milk samples (Correa and Marin, 2002; Lira et al., 2004; Lamey et al., 2013). The E. coli O55 was previously used as a bovine mastitis reference pathogen (Kang et al., 2016); therefore, it was selected in our study. Briefly, $100 \mu \mathrm{L}$ of overnight-incubated E. coli O55 culture was inoculated in $10 \mathrm{~mL}$ of TSB with a different concentration of Mor (100 and $200 \mu \mathrm{g} / \mathrm{mL}$ ) until $10^{8} \mathrm{cfu} / \mathrm{mL}$. Control group was added with $0.1 \%$ DMSO. One milliliter of bacterial culture was centrifuged at $7,800 \times g$ for 5 min at $4^{\circ} \mathrm{C}$. The pellet was resuspended in $1 \mathrm{~mL}$ of cold PBS (Gibco, Grand Island, NY) and treated to a monolayer of MAC-T cells (80-90\% confluency) at a multiplicity of infection (MOI; ratio of bacteria to MAC-T cells) of 10:1 (Döpfer et al., 2000; Bouchard et al., 2013). Escherichia coli-treated MAC-T cells were incubated for 2 $\mathrm{h}$ in a humidified $\mathrm{CO}_{2}$ incubator at $37^{\circ} \mathrm{C}$ (Döpfer et al., 2001). The MAC-T cells were then washed 3 times with PBS. Cells were then detached with $200 \mu \mathrm{L}$ of trypsin (Gibco) and lysed with $800 \mu \mathrm{L}$ of $0.1 \%$ Triton X-100 (Sigma-Aldrich). Cell lysates were serially diluted, plated on TSA, and incubated overnight at $37^{\circ} \mathrm{C}$; number of colonies formed on TSA were counted and expressed as colony-forming units per milliliter. For the invasion assay, a monolayer of MAC-T cells was infected with Mor-treated E. coli O55 at an MOI of 10:1 for $2 \mathrm{~h}$. The cells were washed with PBS, and incubated with fresh Dulbecco's modified Eagle medium supplemented with $100 \mu \mathrm{g} / \mathrm{mL}$ of gentamycin sulfate salt (Sigma-Aldrich). The cells were incubated for another $2 \mathrm{~h}$ to kill the extracellular bacteria. Next, the cells were washed and lysed, and plated on the TSA. The bacterial population was measured as described in the adhesion assay. Invasion was expressed as the total number of $\mathrm{cfu} / \mathrm{mL}$ recovered per well.

The adhesion of $E$. coli is usually regulated by fimbria, the thin and short filamentous proteinaceous structures that extend from the bacterial cell membrane (Le Bouguénec, 2005). We assumed that fimbriae might play a role in adhesion and invasion of E. coli O55 to MAC-T cells; therefore, we investigated the effect of Mor on the gene expressions of adhesion factors [type 1 fimbrin D-mannose specific adhesin (fimH), F17c fimbriae-A $(f 17 c-\mathrm{A}), \mathrm{P}$ fimbrial usher protein $\mathrm{PapC}$ $($ papC), and intimin (eaeA)] in E. coli O55 (Nagy and Fekete, 1999; Wang et al., 2002; Le Bouguénec, 2005). For quantification of mRNA expression of these genes, $100 \mu \mathrm{L}$ of E. coli $\mathrm{O} 55$ was incubated with $200 \mu \mathrm{g} / \mathrm{mL}$ of Mor in $10 \mathrm{~mL}$ of TSB for $4 \mathrm{~h}$. The control group was added with $0.1 \%$ DMSO, which is the amount of Mor added in the treatment group. One $\mathrm{mL}$ of bacterial pellet was obtained via centrifugation at $7,800 \times$ $g$ for $5 \mathrm{~min}$ at $4^{\circ} \mathrm{C}$. The pellet was lysed with $500 \mu \mathrm{L}$ of TRIzol reagent (Life Technologies, Eugene, OR), and RNA was extracted. The cDNA was synthesized using the TOPscript RT DryMIX kit (Enzynomics, Daejeon, Korea). The mRNA expression of genes was analyzed by Real-Time PCR (Roche LightCycler 96 System, Basel, Switzerland) using the Real-Time PCR mix (SolGent, Daejeon, Korea). The PCR conditions were as follows: $95^{\circ} \mathrm{C}$ for $15 \mathrm{~min}$ (denaturation) and 50 cycles of amplification at $95^{\circ} \mathrm{C}$ for $20 \mathrm{~s}$, followed by respective annealing temperature and finally held at $4^{\circ} \mathrm{C}$. The primer sequences (Bionics, Seoul, Korea) used are listed in Table 1. Data analysis was performed via relative quantification method $(\Delta \Delta \mathrm{Cq})$, in which the relative mRNA expression of target mRNA (i.e., fimH, $f 17 c-\mathrm{A}$, papC, and eaeA) was compared with that of a constitutively expressed gene (i.e., E. coli $16 \mathrm{~S}$ rRNA, E16S).

Next, we investigated the effect of Mor in MAC-T cells toward adhesion and invasion of E. coli O55, Enterococcus faecalis, Staphylococcus simulans, and Serratia liquefaciens. Briefly, a monolayer of MAC-T cells was pretreated with $200 \mu \mathrm{g} / \mathrm{mL}$ of Mor for $12 \mathrm{~h}$ (treatment group; with Mor). Concentration and incubation time of Mor were selected based on a previous study (Cheng et al., 2019). The control group (without Mor) was treated with $0.1 \%$ DMSO. Both treatment group and control group were exposed with $10^{8}$ bacterial inoculum at an MOI of 10:1 and 100:1. The adhesion and invasion assays were conducted.

In addition, we investigated whether Mor can improve the antioxidant capacity of MAC-T cells. The mRNA expression levels of antioxidant genes [heme oxygenase-1 (HO-1), NAD (P)H:quinone oxidoreductase-1 (NQO1), and thioredoxin reductase 1 (TXNRD1)] were measured in MAC-T cells. In the treatment group (with Mor), MAC-T cells were pretreated with $200 \mu \mathrm{g} / \mathrm{mL}$ of Mor for $12 \mathrm{~h}$, whereas the control group (without Mor) was treated with $0.1 \%$ DMSO, followed by the addition of $E$. coli O55 to the cells at an MOI of 10:1 and 100:1 for $2 \mathrm{~h}$. The MAC-T cells without E. coli O55 exposure served as controls. The MAC-T cells were collected with $500 \mu \mathrm{L}$ of TRIzol reagent. Same procedures were conducted for RNA extraction, cDNA synthesis, and real-time PCR, as described above. The primers used are shown in Table 1. Data were analyzed using the relative quantification method $(\Delta \Delta \mathrm{Cq})$, in which the relative expression of target mRNA (i.e., HO-1, NQO1, and TXNRD1) was compared with that of a constitutively expressed gene (i.e., GAPDH). 
Table 1. The base sequence and annealing temperatures of target gene primers $(\mathrm{F}=$ forward; $\mathrm{R}=$ reverse $)$

\begin{tabular}{|c|c|c|}
\hline Target gene & Sequence $5^{\prime}-3^{\prime}$ & $\begin{array}{c}\text { Annealing } \\
\text { temperature }\left({ }^{\circ} \mathrm{C}\right)\end{array}$ \\
\hline fimH (Zhang et al., 2018) & $\begin{array}{l}\text { (F) TGCAGAACGGATAAGCCGTGG } \\
\text { (R) GCAGTCACCTGCCCTCCGGTA }\end{array}$ & 60 \\
\hline papC (Ghanbarpour and Oswald, 2010) & $\begin{array}{l}\text { (F) GACGGCTGTACTGCAGGGTGTGGCG } \\
\text { (R) ATATCCTTTCTGCAGGGATGCAATA }\end{array}$ & 55 \\
\hline E16S (Wang et al., 2002) & $\begin{array}{l}\text { (F) CCCCCTGGACGAAGACTGAC } \\
\text { (R) ACCGCTGGCAACAAAGGATA }\end{array}$ & 55 \\
\hline HO-1 (Cheng et al., 2019) & $\begin{array}{l}\text { (F) AGGATTTGTCAGAGGCCCTGAA } \\
\text { (R) CAAAGACGCCATCACCAGCTTA }\end{array}$ & 60 \\
\hline NQO1 (Cheng et al., 2019) & $\begin{array}{l}\text { (F) GGTGCTCATAGGGGAGTTCG } \\
\text { (R) GGGAGTGTGCCCAATGCTAT }\end{array}$ & 60 \\
\hline TXNRD1 (Cheng et al., 2019) & $\begin{array}{l}\text { (F) CGGTATTGCTGGCAATAGGAAGAG } \\
\text { (R) GGCATAGATGTAAGGCACGTTGGT }\end{array}$ & 60 \\
\hline
\end{tabular}

For all the experiments in this study, data were statistically analyzed using IBM SPSS Statistics for Macintosh, Version 23 (IBM, Armonk, NY) by Student's $t$-test. Data were expressed as mean \pm standard error of the mean. $P$-values $<0.05$ were considered statistically significant. Each experiment consisted of 3 replicates and was repeated 3 times.

Table 2 presents the MIC and MBC values of Mor against 27 bacteria. The MIC and MBC of Mor against the 11 gram-negative isolates ranged from 12.5 to $50 \mathrm{mg} / \mathrm{mL}$. On the other hand, MIC of Mor against gram-positive bacteria were either 12.5 to $25 \mathrm{mg} / \mathrm{mL}$ ( 7 out of 16 isolates) or $50 \mathrm{mg} / \mathrm{mL}$ ( 7 out of 16 isolates). The Mor showed no bactericidal effect on 9 out of 16 gram-positive isolates (MBC >50 mg/mL). The bacteriostatic and bactericidal effect of Mor might be attributed to the presence of antimicrobial phytochemical constituents in moringa leaves such as alkaloids, saponins, anthraquinones, tannins, flavonoids, and phenols (Kasolo et al., 2010; Sankhalkar and Vernekar, 2016). These compounds bind to the bacterial cell wall and inhibit microbial growth depending on their type and chemical structure (El Sohaimy et al., 2015). For instance, chlorogenic acid was reported to bind to the outer membrane of Staphylococcus aureus, Shigella dysenteriae, and Streptococcus pneumoniae, and that disrupted the membrane, exhausted the intracellular potential, released cytoplasm macromolecules, and eventually led to bacterial death (Lou et al., 2011; Li et al., 2014). In addition, flavonoids, especially kaempferol and quercetin, are known to inhibit E. coli DNA gyrase involved in bacterial replication (Wu et al., 2013).

The varying degrees of MIC and MBC of Mor against the 27 tested isolates might be attributed to the complexity of the bacterial cell walls. The cell wall of gram-negative bacteria is constructed of 2 layers, a peptidoglycan inner membrane and an outer membrane formed by lipoproteins and LPS that prevents penetration of high molecular weight antibiotics and hydrophilic molecules (Stefanović, 2018). In contrast, the cell wall of gram-positive bacteria, even though it is composed of several layers of peptidoglycan, is mostly permeable to various compounds (Stefanović, 2018). In our study, 7 out of 16 gram-positive isolates had lower

Table 2. Determination of MIC and minimum bactericidal concentration (MBC) of moringa extract (Mor) against 26 isolated bacterial strains and the reference strain Escherichia coli $\mathrm{O} 55$

\begin{tabular}{|c|c|c|c|}
\hline \multicolumn{2}{|c|}{ Mor $(\mathrm{mg} / \mathrm{mL})$} & \multicolumn{2}{|c|}{ Number of isolated bacteria } \\
\hline 12.5 & 25 & 1 & 1 \\
\hline 25 & 25 & 0 & 5 (including E. coli $\mathrm{O} 55$ ) \\
\hline 25 & 50 & 0 & 1 \\
\hline 50 & 50 & 0 & 2 \\
\hline
\end{tabular}


MIC $(\leq 50 \mathrm{mg} / \mathrm{mL}$ Mor) than 11 isolates in gram-negative bacteria, which may be due to the differences in cell walls. Our results are comparable with a previous study by Alzoreky and Nakahara (2003) where methanolic extracts of 26 species of plants were evaluated for inhibitory effects on bacteria growth. The MIC of most plant extracts against gram-positive bacteria (Bacillus cereus, Staphylococcus aureus, and Listeria monocytogenes) ranged from 165 to $2,640 \mathrm{mg} / \mathrm{mL}$; however, only Cinnamomum cassia extract had an antibacterial effect on gram-negative bacteria (E. coli and Salmonella infantis) with MIC of $2,460 \mathrm{mg} / \mathrm{mL}$.

On the other hand, factors such as biofilm, bacterial efflux pumps, and quorum sensing are also important factors for determining MIC and MBC (Winn et al., 2010; Savoia, 2012). In particular, biofilm is known to protect bacteria from environmental stress such as antibiotics and the immune system (Jacques et al., 2010). Biofilm played a role in recurrent infections and antimicrobial agents/host immune defense system resistance; hence, biofilm formers are a difficult target in the control and treatment of bovine mastitis (Gomes et al., 2016). Among 2 identified gram-positive isolates in our study, Staphylococcus simulans (MIC and MBC: 12.5 $\mathrm{mg} / \mathrm{mL}$ Mor) has been reported as a non-biofilm or weak biofilm former (Tremblay et al., 2013; Szczuka et al., 2016; Phophi et al., 2019); and Enterococcus faecalis (MIC and MBC: 50 and $>50 \mathrm{mg} / \mathrm{mL}$ Mor) is a common biofilm producer (Toledo-Arana et al., 2001; Elhadidy and Elsayyad, 2013; Anderson et al., 2016). Therefore, biofilm formation may possibly protect bacteria from Mor and contribute to the high MIC and MBC of Mor, at least in part, in 9 out of 16 gram-positive isolates. However, further studies are necessary to identify the underlying mechanisms.

Figure 1A showed that treatment of E. coli O55 with 100 and $200 \mu \mathrm{g} / \mathrm{mL}$ of Mor significantly decreased the percentage of bacterial adhesion to cells to 72 to $76 \%$, compared with untreated controls $(P<0.05)$. The percentage of invasion was also decreased $(P<0.05)$ to $83 \%$ and $89 \%$ with 100 and $200 \mu \mathrm{g} / \mathrm{mL}$ of Mor-treated E. coli O55, respectively (Figure 1B). Results of realtime PCR showed that Mor treatment $(200 \mu \mathrm{g} / \mathrm{mL})$ decreased the mRNA expression levels of $f 1 \% c-\mathrm{A}$, papC, and eaeA $(P<0.05)$, but not fimH, in E. coli O55 (Figure $1 \mathrm{C}$ to $1 \mathrm{~F})$. These data suggest that Mor decreased adhesion and invasion of E. coli O55 in MAC-T cells by downregulating the fimbrial adhesion factors.

Adhesion of E. coli O55, Enterococcus faecalis, and Staphylococcus simulans to $200 \mu \mathrm{g} / \mathrm{mL}$ Mor-pretreated MAC-T cells was significantly lower than that of the corresponding control (Figure 2A, 2C, and 2E). The invasion of E. coli O55, Enterococcus faecalis, and
Serratia liquefaciens in Mor-pretreated cells was significantly lower than that of the corresponding control (Figure 2B, 2D, and 2H). However, invasion of Staphylococcus simulans in MAC-T cells was higher than that of the control (Figure 2F). The adhesion of Serratia liquefaciens in MAC-T cells was higher than that of the control (Figure 2G). Different adhesion and invasion patterns were observed in the tested bacteria; however, the underlying mechanisms are unclear. One possible speculation is that adhesion and internalization of different bacteria are dependent on different mechanisms; in particular, different bacteria bind to different receptors on host cells. Pretreatment of Mor with MAC-T cells might have affected these receptors. A past study reported that quercetin prevented E. coli O157:H7 adhesion to human colonic epithelial cell line Caco-2 through attenuated expression of integrin $\beta 1$ of Caco-2 cells (Xue et al., 2019). It is also possible that Mor altered only some of the surface receptors of MAC-T cells, which may take part in the adhesions of E. coli O55, Enterococcus faecalis, and Staphylococcus simulans but not Serratia liquefaciens. Further studies are necessary to identify the differential effects of Mor on adhesion and invasion of bacteria and the underlying mechanism.

Antioxidant enzymes, HO-1, NQO1, and TXNRD1, are reported to play protective roles in mammary cells of the Holstein dairy cow during the postpartum period to maintain proper redox homeostasis of the cells (Aitken et al., 2009; Han et al., 2018). Hence, these enzymes have been used as indicators of antioxidant capacities in MAC-T cells (Jin et al., 2016; Wang et al., 2016). The gene expression of $\mathrm{HO}-1$ was increased by E. coli $\mathrm{O} 55$ alone in MAC-T cells (Figure 2I). These results showed that $\mathrm{HO}_{-1}$ is more likely to respond to stimulation of E. coli O55 compared with $N Q O 1$ and TXNRD1. Indeed, HO-1 is a phase II antioxidant or detoxifying enzyme that is activated by several physiological and pathological stimuli such as ROS, cytokines, and bacterial components (Paine et al., 2010). Because HO-1 was reported to play a role in protecting RAW264.7 macrophage against oxidative stress (Cheng et al., 2015), the observed upregulation of $\mathrm{HO}-1$ is probably due to the defensive role of MAC-T cells. In contrast, the expression of NQO1 and TXNRD1 in MAC-T cells was decreased by E. coli O55 (Figure 2J and $\mathrm{K}$ ). Despite the differential expression of these genes in E. coli O55-treated MAC-T cells, pretreatment of MAC-T cells with Mor significantly increased $(P$ $<0.05)$ the level of these genes when compared with untreated groups. These findings indicate the upregulation of antioxidant capacities of MAC-T by Mor. In fact, Mor increased the expression of HO-1, NQO1, and 
TXNRD1 in MAC-T cells challenged by LPS (Cheng et al., 2019). These antioxidant effects are attributed to the rich polyphenol content of $M$. oleifera including flavonoids and phenolic acids, such as quercetin and kaempferol, and these compounds were reported to increase HO-1 protein expression in rat aorta smooth muscle cells and BV-2 microglia cells (Lin et al., 2004; Velagapudi et al., 2019).
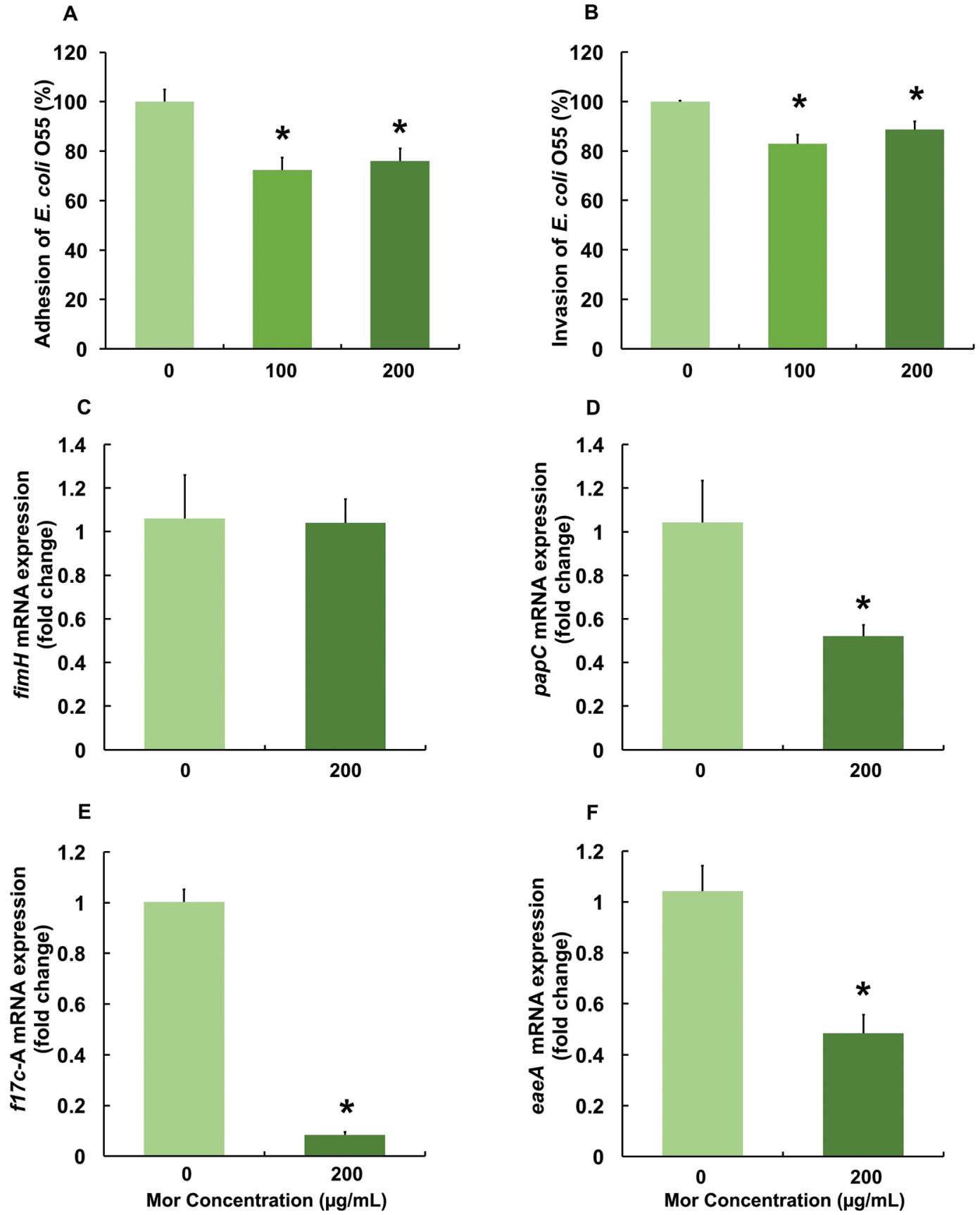

Figure 1. Effect of moringa extract (Mor) on adhesion (A) and invasion (B) of Escherichia coli O55 in bovine mammary epithelial (MAC-T) cells. Activated E. coli $\mathrm{O} 55$ was treated with 0,100 , and $200 \mu \mathrm{g} / \mathrm{mL}$ of Mor until it resulted in $10^{8} \mathrm{cfu} / \mathrm{mL}$. The $E$. coli O55 was then added to the MAC-T monolayer at a multiplicity of infection (MOI; ratio of bacteria to cells) of 10:1 for $2 \mathrm{~h}$. Adhesion and invasion are presented as a percentage of the control. For the measurement of gene expression, E. coli O55 was treated with 0 and $200 \mu \mathrm{g} / \mathrm{mL} \mathrm{Mor} \mathrm{for} 4 \mathrm{~h}$. The mRNA expression levels of fimH $(\mathrm{C}), \operatorname{pap} C(\mathrm{D}), f 17 \mathrm{c}-\mathrm{A}(\mathrm{E})$, and eaeA $(\mathrm{F})$ were measured using real-time (RT) PCR. Details of adhesion, invasion, and RT-PCR are described in the main text of the article. Values represent means \pm SEM $(n=3)$. ${ }^{*}$ Significant difference versus control $($ Mor $=0$ $\mu \mathrm{g} / \mathrm{mL} ; P<0.05)$. 


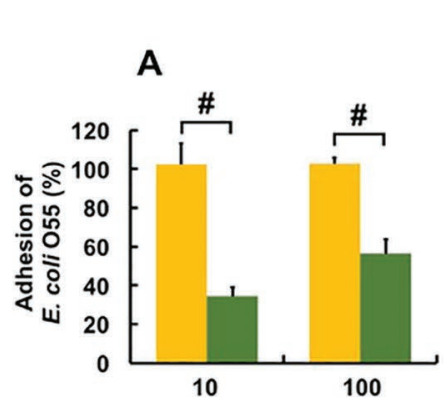

B

W/O Mor
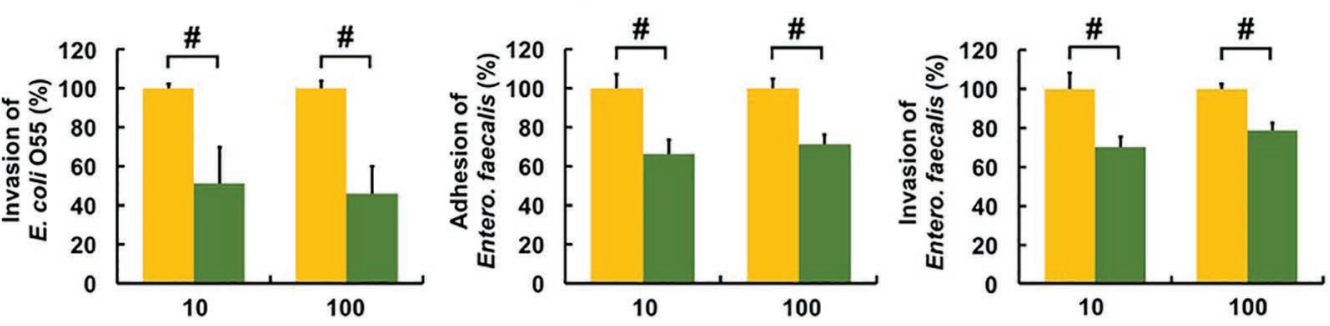

E

$\mathbf{F}$

G

H
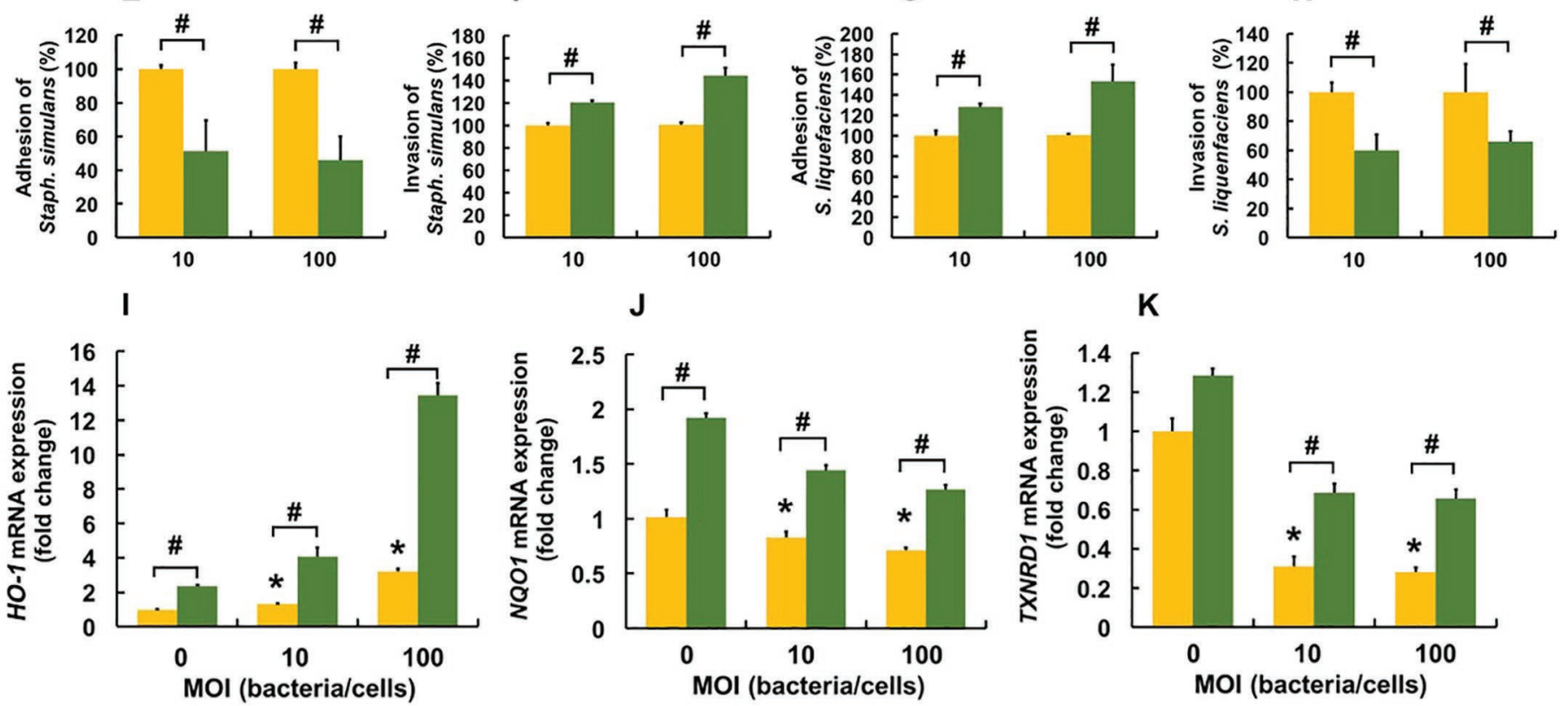

Figure 2. Effect of moringa extract (Mor) on adhesion and invasion by Escherichia coli O55 (A and B), Enterococcus faecalis (C and D), Staphylococcus simulans (E and F), and Serratia liquefaciens ( $\mathrm{G}$ and $\mathrm{H}$ ) in bovine mammary epithelial (MAC-T) cells. The MAC-T cells were pretreated with 0 and $200 \mu \mathrm{g} / \mathrm{mL}$ followed by stimulation with activated bacteria at a multiplicity of infection (MOI; ratio of bacteria to cells) of 10:1 and 100:1. Adhesion and invasion are presented as a percentage of the control. The mRNA expression of HO-1 (I), NQO1 (J), and TXNRD1 (K) was measured using real-time (RT) PCR. Details about adhesion, invasion, and RT-PCR are described in the main text of the article. Values represent means \pm SEM $(\mathrm{n}=3)$. *Significant difference versus control $(\mathrm{MOI}=0 ; P<0.05)$. \#Significant difference between the 2 treatment groups (without Mor and with Mor; $P<0.05$ ).

In conclusion, our data provide evidence that Mor exhibits antipathogenic effects at 12.5 to $50 \mathrm{mg} / \mathrm{mL}$ against 18 out of 27 tested bacterial isolates. Pretreatment of Mor at $200 \mu \mathrm{g} / \mathrm{mL}$ to E. coli O55 decreased its adhesion and invasion in MAC-T cells by modulating the adhesion factors of $E$. coli $\mathrm{O} 55$. In addition, pretreatment of MAC-T cells with Mor $(200 \mu \mathrm{g} / \mathrm{mL}, 12 \mathrm{~h})$ decreased the adhesion of E. coli O55, Enterococcus faecalis, and Staphylococcus simulans on the cells. Furthermore, pretreatment of MAC-T cells with Mor increased the antioxidant capacity of MAC-T cells through increased expression of antioxidant genes. Although further animal studies are needed, our data suggest that $M$. oleifera can be potentially supplemented to dairy cow feed to protect the mammary glands against IMI.

\section{ACKNOWLEDGMENTS}

The authors have no funding to report. The authors have stated no conflicts of interest.

\section{REFERENCES}

Aitken, S. L., E. L. Karcher, P. Rezamand, J. C. Gandy, M. J. VandeHaar, A. V. Capuco, and L. M. Sordillo. 2009. Evaluation of antioxidant and proinflammatory gene expression in bovine mammary tissue during the periparturient period. J. Dairy Sci. 92:589-598. https://doi.org/10.3168/jds.2008-1551.

Alzoreky, N. S., and K. Nakahara. 2003. Antibacterial activity of extracts from some edible plants commonly consumed in Asia. Int. J. Food Microbiol. 80:223-230. https://doi.org/10.1016/S0168 $-1605(02) 00169-1$.

Anderson, A. C., D. Jonas, I. Huber, L. Karygianni, J. Wölber, E. Hellwig, N. Arweiler, K. Vach, A. Wittmer, and A. Al-Ahmad. 
2016. Enterococcus faecalis from food, clinical specimens, and oral sites: Prevalence of virulence factors in association with biofilm formation. Front. Microbiol. 6:1534. https://doi.org/10.3389/ fmicb.2015.01534.

Atawodi, S. E., J. C. Atawodi, G. A. Idakwo, B. Pfundstein, R. Haubner, G. Wurtele, H. Bartsch, and R. W. Owen. 2010. Evaluation of the polyphenol content and antioxidant properties of methanol extracts of the leaves, stem, and root barks of Moringa oleifera Lam. J. Med. Food 13:710-716. https://doi.org/10.1089/jmf.2009.0057.

Bernabucci, U., B. Ronchi, N. Lacetera, and A. Nardone. 2005. Influence of body condition score on relationships between metabolic status and oxidative stress in periparturient dairy cows. J. Dairy Sci. 88:2017-2026. https://doi.org/10.3168/jds.S0022 $-0302(05) 72878-2$.

Bouchard, D. S., L. Rault, N. Berkova, Y. Le Loir, and S. Even. 2013. Inhibition of Staphylococcus aureus invasion into bovine mammary epithelial cells by contact with live Lactobacillus casei. Appl. Environ. Microbiol. 79:877-885. https://doi.org/10.1128/AEM.03323 -12 .

Cheng, W. N., C. H. Jeong, H. G. Seo, and S. G. Han. 2019. Moringa extract attenuates inflammatory responses and increases gene expression of casein in bovine mammary epithelial cells. Animals (Basel) 9:391. https://doi.org/10.3390/ani9070391.

Cheng, X., D. X. Gao, J. J. Song, F. Z. Ren, and X. Y. Mao. 2015. Casein glycomacropeptide hydrolysate exerts cytoprotection against $\mathrm{H}_{2} \mathrm{O}_{2}$-induced oxidative stress in RAW 264.7 macrophages via ROS-dependent heme oxygenase-1 expression. RSC Advances 5:4511-4523. https://doi.org/10.1039/C4RA10034D.

CLSI. 2018. Methods for dilution antimicrobial susceptibility tests for bacterial that grow aerobically. 10th ed. Clinical and Laboratory Standards Institute, Wayne, PA.

Correa, M. G., and J. Marin. 2002. O-serogroups, eae gene and EAF plasmid in Escherichia coli isolates from cases of bovine mastitis in Brazil. Vet. Microbiol. 85:125-132. https://doi.org/10.1016/S0378 -1135(01)00413-8.

Döpfer, D., R. Almeida, T. Lam, H. Nederbragt, S. Oliver, and W. Gaastra. 2000. Adhesion and invasion of Escherichia coli from single and recurrent clinical cases of bovine mastitis in vitro. Vet. Microbiol. 74:331-343. https://doi.org/10.1016/S0378-1135(00)00191 -7 .

Döpfer, D., H. Nederbragt, R. Almeida, and W. Gaastra. 2001. Studies about the mechanism of internalization by mammary epithelial cells of Escherichia coli isolated from persistent bovine mastitis. Vet. Microbiol. 80:285-296. https://doi.org/10.1016/S0378 $-1135(01) 00307-8$

El Sohaimy, S. A., G. M. Hamad, S. E. Mohamed, M. H. Amar, and R. R. Al-Hindi. 2015. Biochemical and functional properties of Moringa oleifera leaves and their potential as a functional food. Glob. Adv. Res. J. Agric. Sci. 4:188-199.

Elhadidy, M., and A. Elsayyad. 2013. Uncommitted role of enterococcal surface protein, Esp, and origin of isolates on biofilm production by Enterococcus faecalis isolated from bovine mastitis. J. Microbiol. Immunol. Infect. 46:80-84. https://doi.org/10.1016/j.jmii .2012.02.002.

Erskine, R. J., S. Wagner, and F. J. DeGraves. 2003. Mastitis therapy and pharmacology. Vet. Clin. North Am. Food Anim. Pract. 19:109-138. https://doi.org/10.1016/S0749-0720(02)00067-1.

Ghanbarpour, R., and E. Oswald. 2010. Phylogenetic distribution of virulence genes in Escherichia coli isolated from bovine mastitis in Iran. Res. Vet. Sci. 88:6-10. https://doi.org/10.1016/j.rvsc.2009 .06 .003 .

Gogoi-Tiwari, J., C. B. Waryah, K. Y. Eto, M. Tau, K. Wells, P. Costantino, H. K. Tiwari, S. Isloor, N. Hegde, and T. Mukkur. 2015. Relative distribution of virulence-associated factors among Australian bovine Staphylococcus aureus isolates: Potential relevance to development of an effective bovine mastitis vaccine. Virulence 6:419-423. https://doi.org/10.1080/21505594.2015.1043508.

Gomes, F., N. Martins, I. C. Ferreira, and M. Henriques. 2019. Antibiofilm activity of hydromethanolic plant extracts against Staphylococcus aureus isolates from bovine mastitis. Heliyon 5:e01728. https://doi.org/10.1016/j.heliyon.2019.e01728.
Gomes, F., M. J. Saavedra, and M. Henriques. 2016. Bovine mastitis disease/pathogenicity: Evidence of the potential role of microbial biofilms. Pathog. Dis. 74:ftw006. https://doi.org/10.1093/femspd/ ftw006.

Gopalakrishnan, L., K. Doriya, and D. S. Kumar. 2016. Moringa oleifera: A review on nutritive importance and its medicinal application. Food Sci. Hum. Wellness 5:49-56. https://doi.org/10.1016/j .fshw.2016.04.001.

Halasa, T., K. Huijps, O. Østerås, and H. Hogeveen. 2007. Economic effects of bovine mastitis and mastitis management: A review. Vet. Q. 29:18-31. https://doi.org/10.1080/01652176.2007.9695224.

Han, L. Q., Z. Zhou, Y. Ma, F. Batistel, J. S. Osorio, and J. J. Loor. 2018. Phosphorylation of nuclear factor erythroid 2-like 2 (NFE2L2) in mammary tissue of Holstein cows during the periparturient period is associated with mRNA abundance of antioxidant gene networks. J. Dairy Sci. 101:6511-6522. https://doi.org/10 $.3168 /$ jds.2017-14257.

Jacques, M., V. Aragon, and Y. D. Tremblay. 2010. Biofilm formation in bacterial pathogens of veterinary importance. Anim. Health Res. Rev. 11:97-121. https://doi.org/10.1017/S1466252310000149.

Jeong, C. H., W. N. Cheng, H. Bae, K. W. Lee, S. M. Han, M. C. Petriello, H. G. Lee, H. G. Seo, and S. G. Han. 2017. Bee venom decreases LPS-induced inflammatory responses in bovine mammary epithelial cells. J. Microbiol. Biotechnol. 27:1827-1836. https:// doi.org/10.4014/jmb.1706.06003.

Jin, X., K. Wang, H. Liu, F. Hu, F. Zhao, and J. Liu. 2016. Protection of bovine mammary epithelial cells from hydrogen peroxideinduced oxidative cell damage by resveratrol. Oxid. Med. Cell. Longev. 2016:1-15. https://doi.org/10.1155/2016/2572175.

Kang, S. J., Y. I. Cho, K. H. Kim, and E. S. Cho. 2016. Proteomic analysis to elucidate the antibacterial action of silver ions against bovine mastitis pathogens. Biol. Trace Elem. Res. 171:101-106. https://doi.org/10.1007/s12011-015-0510-5.

Kasolo, J. N., G. S. Bimenya, L. Ojok, J. Ochieng, and J. W. OgwalOkeng. 2010. Phytochemicals and uses of Moringa oleifera leaves in Ugandan rural communities. J. Med. Plants Res. 4:753-757. https://doi.org/10.5897/JMPR10.492.

Lamey, A., A. M. Ammar, E. Zaki, N. Khairy, B. Moshref, and M. K. Refai. 2013. Virulence factors of Escherichia coli isolated from recurrent cases of clinical and subclinical mastitis in buffaloes. Int. J. Microbiol. Res. 4:86-94. https://doi.org/10.5829/idosi.ijmr .2013.4.1.71103.

Le Bouguénec, C. 2005. Adhesins and invasins of pathogenic Escherichia coli. Int. J. Med. Microbiol. 295:471-478. https://doi.org/ 10.1016/j.ijmm.2005.07.001.

Lewis, K., and F. M. Ausubel. 2006. Prospects for plant-derived antibacterials. Nat. Biotechnol. 24:1504-1507. https://doi.org/10 $.1038 /$ nbt1206-1504.

Li, G., X. Wang, Y. Xu, B. Zhang, and X. Xia. 2014. Antimicrobial effect and mode of action of chlorogenic acid on Staphylococcus aureus. Eur. Food Res. Technol. 238:589-596. https://doi.org/10 .1007/s00217-013-2140-5.

Lin, H. C., T. H. Cheng, Y. C. Chen, and S. H. Juan. 2004. Mechanism of heme oxygenase-1 gene induction by quercetin in rat aortic smooth muscle cells. Pharmacology 71:107-112. https://doi.org/ $10.1159 / 000076947$.

Lira, W. M., C. Macedo, and J. Marin. 2004. The incidence of Shiga toxin-producing Escherichia coli in cattle with mastitis in Brazil. J. Appl. Microbiol. 97:861-866. https://doi.org/10.1111/j.1365 $-2672.2004 .02384 . x$.

Lou, Z., H. Wang, S. Zhu, C. Ma, and Z. Wang. 2011. Antibacterial activity and mechanism of action of chlorogenic acid. J. Food Sci. 76:M398-M403. https://doi.org/10.1111/j.1750-3841.2011.02213 .x.

Momtaz, H., F. Safarpoor Dehkordi, T. Taktaz, A. Rezvani, and S. Yarali. 2012. Shiga toxin-producing Escherichia coli isolated from bovine mastitic milk: Serogroups, virulence factors, and antibiotic resistance properties. ScientificWorldJournal 2012:618709. https:/ /doi.org/10.1100/2012/618709.

Mushtaq, S., M. A. Rather, P. H. Qazi, M. A. Aga, A. M. Shah, A. Shah, and M. N. Ali. 2016. Isolation and characterization of three 
benzylisoquinoline alkaloids from Thalictrum minus L. and their antibacterial activity against bovine mastitis. J. Ethnopharmacol. 193:221-226. https://doi.org/10.1016/j.jep.2016.07.040.

Nagy, B., and P. Z. Fekete. 1999. Enterotoxigenic Escherichia coli (ETEC) in farm animals. Vet. Res. 30:259-284.

Nouman, W., F. Anwar, T. Gull, A. Newton, E. Rosa, and R. Domínguez-Perles. 2016. Profiling of polyphenolics, nutrients and antioxidant potential of germplasm's leaves from seven cultivars of Moringa oleifera Lam. Ind. Crops Prod. 83:166-176. https://doi .org/10.1016/j.indcrop.2015.12.032.

Oliver, S. P., and L. M. Sordillo. 1988. Udder health in the periparturient period. J. Dairy Sci. 71:2584-2606. https://doi.org/10.3168/ jds.S0022-0302(88)79847-1.

Oviedo-Boyso, J., J. J. Valdez-Alarcón, M. Cajero-Juárez, A. OchoaZarzosa, J. E. López-Meza, A. Bravo-Patino, and V. M. BaizabalAguirre. 2007. Innate immune response of bovine mammary gland to pathogenic bacteria responsible for mastitis. J. Infect. 54:399409. https://doi.org/10.1016/j.jinf.2006.06.010.

Paine, A., B. Eiz-Vesper, R. Blasczyk, and S. Immenschuh. 2010. Signaling to heme oxygenase-1 and its anti-inflammatory therapeutic potential. Biochem. Pharmacol. 80:1895-1903. https://doi.org/10 .1016/j.bcp.2010.07.014.

Phophi, L., I. M. Petzer, and D. N. Qekwana. 2019. Antimicrobial resistance patterns and biofilm formation of coagulase-negative Staphylococcus species isolated from subclinical mastitis cow milk samples submitted to the Onderstepoort Milk Laboratory. BMC Vet. Res. 15:420. https://doi.org/10.1186/s12917-019-2175-3.

Rakholiya, K. D., M. J. Kaneria, and S. V. Chanda. 2013. Medicinal plants as alternative sources of therapeutics against multidrugresistant pathogenic microorganisms based on their antimicrobial potential and synergistic properties. Pages 165-179 in Fighting Multidrug Resistance with Herbal Extracts, Essential Oils and Their Components. M. K. Rai and K. V. Kon, ed. Academic Press, London, UK.

Safari, M., E. Ghasemi, M. Alikhani, and S. Ansari-Mahyari. 2018. Supplementation effects of pomegranate by-products on oxidative status, metabolic profile, and performance in transition dairy cows. J. Dairy Sci. 101:11297-11309. https://doi.org/10.3168/jds .2018-14506.

Sankhalkar, S., and V. Vernekar. 2016. Quantitative and qualitative analysis of phenolic and flavonoid content in Moringa oleifera Lam and Ocimum tenuiflorum L. Pharmacognosy Res. 8:16-21. https:/ /doi.org/10.4103/0974-8490.171095.

Savoia, D. 2012. Plant-derived antimicrobial compounds: Alternatives to antibiotics. Future Microbiol. 7:979-990. 10.2217/fmb.12.68.

Sordillo, L. M. 2018. Mammary gland immunobiology and resistance to mastitis. Vet. Clin. Food Anim. Pract. 34:50 7-523. https://doi .org/10.1016/j.cvfa.2018.07.005.

Sordillo, L. M., and S. L. Aitken. 2009. Impact of oxidative stress on the health and immune function of dairy cattle. Vet. Immunol. Immunopathol. 128:104-109. https://doi.org/10.1016/j.vetimm.2008 .10 .305 .

Stefanović, O. D. 2018. Synergistic Activity of Antibiotics and Bioactive Plant Extracts: A Study Against Gram-Positive and GramNegative Bacteria. Pages 23-48 in Bacterial Pathogenesis and Antibacterial Control. S. Kırmusaoğlu, ed. IntechOpen, London, UK.

Szczuka, E., L. Jabłońska, and A. Kaznowski. 2016. Coagulase-negative staphylococci: pathogenesis, occurrence of antibiotic resistance genes and in vitro effects of antimicrobial agents on biofilm- growing bacteria. J. Med. Microbiol. 65:1405-1413. https://doi .org/10.1099/jmm.0.000372.

Toledo-Arana, A., J. Valle, C. Solano, M. J. Arrizubieta, C. Cucarella, M. Lamata, B. Amorena, J. Leiva, J. R. Penadés, and I. Lasa. 2001. The enterococcal surface protein, Esp, is involved in Enterococcus faecalis biofilm formation. Appl. Environ. Microbiol. 67:4538-4545. https://doi.org/10.1128/AEM.67.10.4538-4545 2001.

Tremblay, Y. D., D. Lamarche, P. Chever, D. Haine, S. Messier, and M. Jacques. 2013. Characterization of the ability of coagulasenegative staphylococci isolated from the milk of Canadian farms to form biofilms. J. Dairy Sci. 96:234-246. https://doi.org/10.3168/ jds.2012-5795.

Velagapudi, R., F. Jamshaid, I. Lepiarz, F. O. Katola, K. Hemming, and O. A. Olajide. 2019. The tiliroside derivative, 3-O- $[(\mathrm{E})-(2-$ oxo-4-(p-tolyl) but-3-en-1-yl) kaempferol produced inhibition of neuroinflammation and activation of AMPK and Nrf2/HO-1 pathways in BV-2 microglia. Int. Immunopharmacol. 77:105951. https: //doi.org/10.1016/j.intimp.2019.105951.

Vergara-Jimenez, M., M. Almatrafi, and M. Fernandez. 2017. Bioactive components in Moringa oleifera leaves protect against chronic disease. Antioxidants 6:91. https://doi.org/10.3390/antiox6040091.

Wang, G., C. G. Clark, and F. G. Rodgers. 2002. Detection in Escherichia coli of the genes encoding the major virulence factors, the genes defining the O157: H7 serotype, and components of the type 2 Shiga toxin family by multiplex PCR. J. Clin. Microbiol. 40:3613-3619. https://doi.org/10.1128/JCM.40.10.3613-3619 2002.

Wang, K., X. L. Jin, X. G. Shen, L. P. Sun, L. M. Wu, J. Q. Wei, M. C. Marcucci, F. L. Hu, and J. X. Liu. 2016. Effects of Chinese propolis in protecting bovine mammary epithelial cells against mastitis pathogens-induced cell damage. Mediators Inflamm. 2016:8028291. https://doi.org/10.1155/2016/8028291.

Watts, J. L. 1988. Etiological agents of bovine mastitis. Vet. Microbiol. 16:41-66. https://doi.org/10.1016/0378-1135(88)90126-5.

Winn, M., R. J. Goss, K.-i. Kimura, and T. D. Bugg. 2010. Antimicrobial nucleoside antibiotics targeting cell wall assembly: Recent advances in structure-function studies and nucleoside biosynthesis. Nat. Prod. Rep. 27:279-304. https://doi.org/10.1039/B816215H.

Wu, T., X. Zang, M. He, S. Pan, and X. Xu. 2013. Structure-activity relationship of flavonoids on their anti-Escherichia coli activity and inhibition of DNA gyrase. J. Agric. Food Chem. 61:8185-8190. https://doi.org/10.1021/jf402222v.

Xue, Y., M. Du, and M. Zhu. 2019. Quercetin prevents Escherichia coli O157: H7 adhesion to epithelial cells via suppressing focal adhesions. Front. Microbiol. 9:3278. https://doi.org/10.3389/fmicb .2018.03278.

Zhang, D., Z. Zhang, C. Huang, X. Gao, Z. Wang, Y. Liu, C. Tian, W. Hong, S. Niu, and M. Liu. 2018. The phylogenetic group, antimicrobial susceptibility, and virulence genes of Escherichia coli from clinical bovine mastitis. J. Dairy Sci. 101:572-580. https:// doi.org/10.3168/jds.2017-13159.

\section{ORCIDS}

W. N. Cheng (ํ) https://orcid.org/0000-0001-5393-2926 S. G. Han ( ) https://orcid.org/0000-0002-1485-861X 